\title{
IMPROVED METHOD OF TROPOSPHERE COMMUNICATION WITH THE MULTI-MIMO SYSTEM ON THE BASE OF FLAT DIGITAL ANTENNA ARRAY
}

\author{
V.I. Slyusar, M.O. Masesov
}

In the article improved method of troposphere communication with the use of technology of multi-MIMO on the base of by flat digital antenna array is presented. The resulted method differs from the known diagrams of orientation of antenna elements of flat array in vertical and horizontal planes. The offered ideas extend scientific base for applications of digital arrays in troposphere communication, render assistance to the increase of firmness of work of the system in the conditions of radioelectronic counteraction of opponent and increase of speed of passing information.

Keywords: troposphere communication, digital beamforming, digital antenna array.

УДК 621.384 .3

\author{
В.І. Боженко ${ }^{1}$, Р.В.Казмірчук ${ }^{1}$, В.І.Шклярський ${ }^{2}$, П.О.Кондратов ${ }^{2}$ \\ ${ }^{1}$ Академія сухопутних військ імені гетьмана Петра Сагайдачного, Львів \\ ${ }^{2}$ Національний університет «Львівська політехніка», Львів
}

\section{МОЖЛИВІ МЕТОДИ ФОРМУВАННЯ КОМПЛЕКСНИХ ТЕПЛОВІЗІЙНИХ ЗОБРАЖЕНЬ}

Багатоспектральне зображення значно полегшує контроль та ідентифікацію об'єктів. Перехід від окремих зображень у різних діапазонах спектру до формування комплексного багатоспектрального зображення істотно підвищуе ефективність моніторингу досліджуваного об'єкту. У даній статті розглянуті різні способи реалізаиї багатоспектральних пристроїв, проблеми, що виникають при иьому, та шляхи їх подолання. Запропоновано комплекс обробки тепловізійного зображення, призначений для формування комплексного дводіапазонного зображення.

Ключові слова: багатоспектральний моніторинг, комплексне зображення, тепловізійна камера

\section{Вступ}

Постановка проблеми. Контроль та аналіз зображень, отриманих у різних спектральних діапазонах, відіграють важливу роль при визначенні ступеня аварійності різних об’єктів, особливо у тих спектральних діапазонах, що перебувають за межами сприйняття людського ока. Перш за все це тепловізійні камери (ТК), чутливі до ближнього (1..5 мкм) та далекого (8...14 мкм) інфрачервоного (IЧ) випромінення. Водночас вплив таких відомих фізичних явищ, як теплова дифузія і теплове маскування, значною мірою спотворюють теплову картину, ускладнюючи точне визначення координат місць із граничною температурою [1].

Наприклад, у області спектру 1,4 - 1,8 мкм можливо ідентифікувати об'єкти до певного ступеню у деяких димах та у пилюці, а також візуалізовувати випромінення сучасних лазерних цілевказівників-далекомірів, що працюють на довжині хвилі 1,55 та 1,7 мкм. 3 цією метою вельми результативним $€$ застосування приладів нічного бачення, що працюють у області спектру 1,42,0 мкм. На рис. 1 наведені криві відбивальної здатності форми військовослужбовця колишнього СРСР (крива 1), форми солдата США (крива 2) та природної рослинності (крива 3) [2]. 3 нього видно, що у області спектру 1,4-2,0 мкм різниця у відбивальній здатності обмундирування дозволяє не лише виокремити вояка на тлі рослинності, але й провести ідентифікацію за принципом «свійчужий».

Загальновідомо, що метою застосування камуфляжу є маскування різноманітних об'єктів на тлі оточуючого середовища. Однак камуфляж, розроблений для видимої області спектру, $\epsilon$ неефективним для області спектру 1,4-1,8 мкм. Для неї узор камуфляжу зникає, та лишається видимим силует замаскованого об'єкту. 


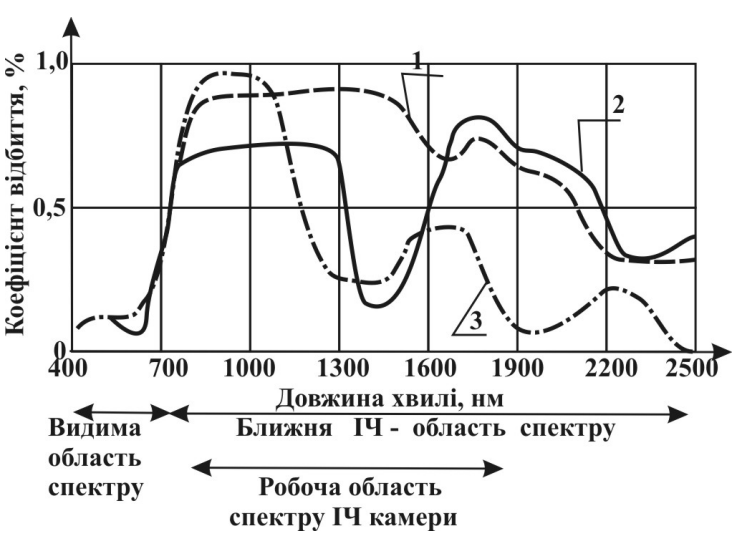

Рис. 1. Криві відбивальної здатності:

1 - форми військовослужбовців колишнього СРСР; 2 - форми військовослужбовців США; 3 - природної рослинності

У області спектру 1,4-1,8 мкм можливо також бачити у тумані та віднаходити сліди криги на дахах літаків на льоновищах, подібні до «чорної» криги на дорогах. Її неможливо помітити у видимій області спектру, але можна побачити у області спектру 1,4-1,8 мкм.

До речі, у цій же області можна віднайти на картинах більш ранній живопис, «похований» під шаром масляних фарб. Досягається це завдяки тому, що велика кількість пігментів масляних фарб, що фарбують світло у видимій області спектру, є прозорими в області 1-2 мкм [2].

Але у більшості випадків дешифрація теплових зображень стикається 3 певними складнощами. Зокрема, визначенню координат фрагментів об'єкту i3 граничними характеристиками перешкоджають такі відомі явища, як відмінність коефіцієнтів випромінення різних частин об'єкту, термодифузія, сегнетоефект тощо. Це призводить до маскування контурів фрагментів зображення в певному спектральному діапазоні та спотворення зображення в цілому. Для запобігання цьому тепловий моніторинг бажано вести одночасно у кількох зонах ІЧ діапазону, а для полегшення ідентифікації теплового зображення i його координатної прив'язки до місцевості та визначення місцезнаходження його ділянок 3 аномальним тепловим станом оператору пред'являють паралельно 3 тепловим ще й видиме зображення (рис. 2-3).
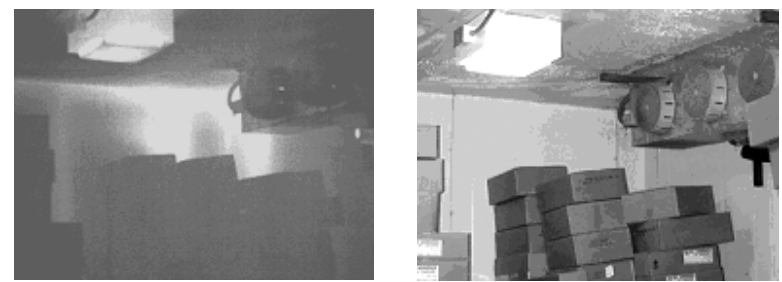

Рис. 2. Фотографії складського приміщення: 1 - у інфрачервоному діапазоні; 2 - у видимому діапазоні

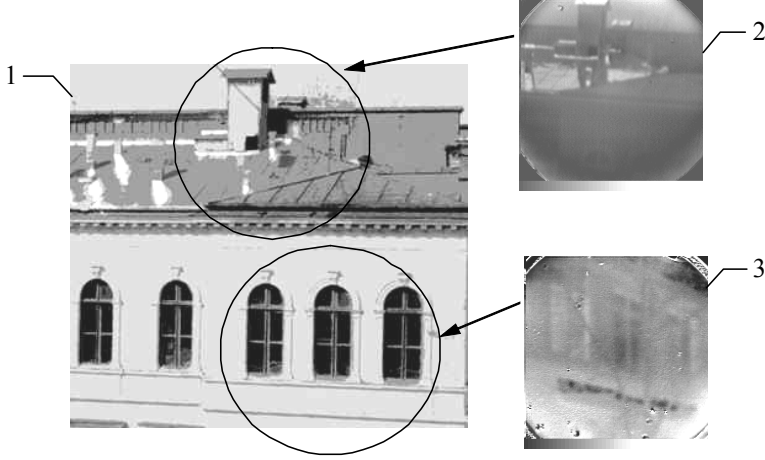

Рuc. 3. Зображення будівлі, отримане у видимому діапазоні (1) та його фрагментів (2), (3) у інфрачервоному діапазоні

У зв'язку 3 низьким ступенем кореляції видимого зображення із зображенням, отриманим у інфрачервоному діапазоні, точність спостереження об'єктів теплового моніторингу значно зросте при реалізації систем комплексного спостереження типу 2D, 3D чи 4D, у якій, крім однієї чи двох TK, є одна чи кілька телевізійних камер (ТВК). Необхідним доповненням такої комплексної системи буде комп'ютер (або цифровий процесор обробки зображення) 3 вузлами інтерфейсу та спеціальним програмним забезпеченням для корекції, сполучення і комплексного відображення зображень об'єкта, отриманих у різних зонах спектрального діапазону.

Відтак мета статті полягає у визначенні ефективних методів та пристроїв формування комплексних зображень. Під “комплексним” автори розуміють зображення, формоване 3 кількох первинних зображень, отриманих у кількох спектральних зонах.

\section{Аналіз відомих методів формування комплексних зображень}

Через неузгодженість характеристик оптичних i електронних каналів реальних ТВК i TK формування комплексного зображення є непростим завданням.

Комплексні зображення можна розділити на [3]:

• “Фрагментарні”, отримані через з’єднання окремих фрагментів, отриманих у різних спектральних зонах, визначених відповідно до передбачуваного спектрального випромінювання досліджуваного об'єкту;

• “Накладені”, що складається, наприклад, 3 чорно-білого або контурного зображення об'єкта у видимому (як правило) діапазоні i псевдокольорового (чи напівтонового) зображення об’єкту в ІЧ діапазоні;

• “Напівпрозорі”, у яких одне 3 зображень є тлом, на якому формується інше зображення, a їх 
сполучення визначається за заздалегідь визначеним (оператором або програмно) пріоритетом для кожного з них.

У випадку, коли комп'ютеризована мультиспектральна система не забезпечує необхідної швидкості формування комплексних зображень, необхідна розробка відповідних апаратних засобів. При цьому важлива просторова суміщеність трьох основних компонентів такої системи:

- детекторів;

- вузлів розгортки;

- оптичних каналів.

Прикладом може служити двоспектральний тепловізор AGA 720 (або Thermovision 300) [4], що складається 3 двох вузькодіапазонних сканерів, змонтованих в одному корпусі. Спеціальні органи регулювання вертикального рівня i паралакса забезпечують їхній напрямок на один об'єкт. Можливе застосування двоканальної оптичної системи зсуву на рівнобіжних променях, де один 3 об'єктивів має суміщення $\Delta \mathrm{l}$ щодо осі детектора. При використанні об'єктивів 3 однаковими характеристиками $(\mathrm{F} 1=\mathrm{F} 2)$ необхідна величина $\Delta \mathrm{l}$ складає:

$$
\Delta l=\frac{d(k+1)}{k^{2}+k+1},
$$

де $k$ - кратність передачі зображення об’єкта.

Величину суміщення можна зменшити вдвічі, якщо реалізувати симетричну схему розміщення об'єктивів. Тоді необхідна величина осьового зсуву для кожного з них $\Delta$ Іс складе:

$$
\Delta l_{c}=\Delta l / 2,
$$

Застосування всехвильової дзеркальної оптики дозволяє реалізувати кілька різновидів мультспектральних схем. Найпростіша - на базі CCD матриці. Конструкція матриці виконана так, що рядки елементів, чуттєвих до видимого випромінення, чергуються з рядками ІЧ детекторів. Селекція сигналів видимого і ІЧ спектрів здійснюється за допомогою дискового обтюратора із синхронним приводом, що містить сектора, оптично прозорі і непрозорі для кожної 3 спектральних складових [5]. Простота функціональної схеми самого пристрою, з'єднана 3 технологічною складністю матриці, висока вартість виготовлення якої значною мірою визначає високу ціну такого пристрою для споживача.

У зв'язку з цим пропонується використовувати значно простіші приймачі у виді лінійок одно- та багатоелементних детекторів, чутливих до випромінення у відповідних спектральних зонах. Разом 3 ними можна використати дзеркальну оптику й одно- та двокоординатні всехвильові схеми розгортки зображення. Такі схеми розгортки можуть бути реалізовані, наприклад, на дзеркальних барабанах чи призмах, а за допомогою напівпрозорих чи дихроїчних і поворотних дзеркал відбувається одночасна передача різних спектральних складових [6].

Для спрощення синтезу багатоспектральних пристроїв пропонується модульний принцип їх побудови. При цьому основною вимогою $\epsilon$ конструктивна й електронна сумісність модульних елементів. Ї̈ї виконання полегшується, якщо детектори, що працюють у різних спектральних діапазонах, належать до одного типу перетворювачів (наприклад, відикон-піровідикон). Якщо ж в одному пристрої об'єднана, наприклад, CCD ТВК і ТК на піровідиконі [7], роблять координатну прив'язку (відповідною адресацією рецепторних полів обох камер).

\section{Пропонований комплекс обробки тепловізійного зображення}

Розглянемо реалізацію вищенаведених рекомендацій.

У пропонованому пристрої видима спектральна зона випромінення теплового об'єкта використовується для генерації контурного чорнобілого зображення. А псевдокольорове теплове зображення розфарбовує цей контур залежно від розподілу температури в різних частинах об'єкту.

Зауважимо, що ТВК та ТК можуть працювати 3 однотипними процесорами покадрової обробки. Це дозволяє реалізувати на їх базі два дуже схожих алгоритми поелементного взаємовилучення відеосигналів у двох суміжних кадрах.

Покадрова обробка у видимій зоні спектру передбачає:

- $\quad$ зміну апертури зчитування (дефокусування) в суміжному кадрі;

- різницеву обробку зображень (РО3) суміжних кадрів:

$$
\begin{gathered}
\Delta U_{i}=U_{i}-U_{i-1} ; \\
\text { - порівняння } \quad \text { різницевого сигналу }
\end{gathered}
$$
визначеним порогом Up:

$$
\Delta U_{t}=\left\{\begin{array}{l}
0, \Delta U_{t}<U_{p} \\
1, \Delta U_{t}>U_{p}
\end{array} .\right.
$$

Піксели з $\Delta \mathrm{Ui}=1$ утворюють бінарне контурне зображення теплового об'єкту у видимій зоні спектру.

PO3 (рис. 3) також використовується для компенсації постійної складової (п’єдесталу) та подвоєння корисної складової при роботі ТК у режимі обтюрації. 


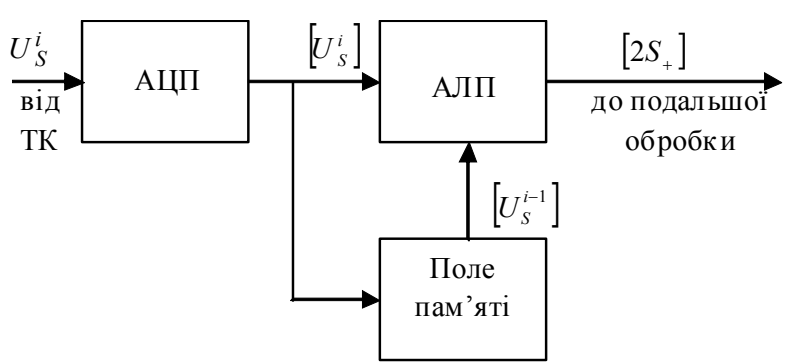
Рис. 3. Структура комплексу різницевої обробки
зображень

Сформований різницевий код надходить на вхід модуля псевдокольорового розфарбування, на виході якого формуються складові RGB (рис. 4).

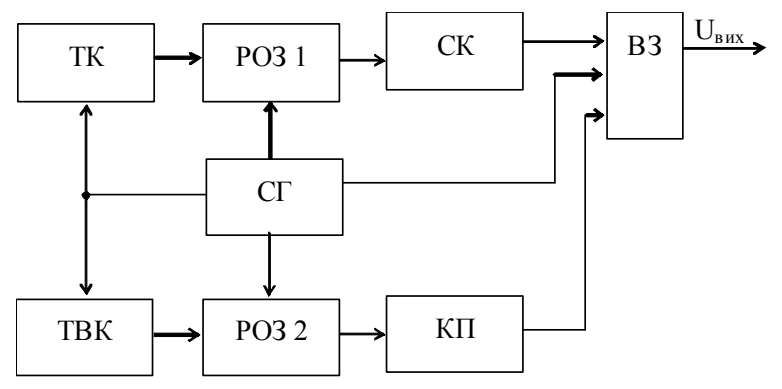

Рuc. 4. Пропонований пристрій формування комплексного зображення, де:

СГ- синхрогенератор; СК - синтезатор кольору; КП - компаратор; В3 - відеозмішувач

У випадку, коли зображення, отримані у окремих діапазонах, будуть певним чином оброблені та шляхом їх суміщення та взаємної координатної прив'язки їх елементів будуть об'єднані у єдине багатоспектральне комплексне зображення, то це значно спростить дії оператора щодо визначення та ідентифікації ділянок об'єктів і систем 3 граничними параметрами та підвищить оперативність їх діагностики.

Пропонований тепловізійний комплекс має відповідати таким основним вимогам:

- достатня розповсюдженість застосовуваних комплектуючих, в першу чергу - теплового детектора, та поміркована ціна ТК в цілому, що уможливило б іiі широке застосування;

- здатність роботи у температурному діапазоні, типовому для задач теплового моніторингу $\left(-20 \ldots+50^{\circ} \mathrm{C}\right)$

- такі теплова і просторова роздільні здатності, що забезпечують необхідну якість теплового зображення;

- масогабарити та енергоспоживання, що відповідають вимогам до автономної переносної апаратури;

- можливість оперативного відтворення отриманого зображення;
- стандартний телевізійний сигнал на виході TK;

- значний ресурс роботи;

- простота керування;

- достатньо розвинені сервісні функції.

Остання вимога може бути конкретизована як можливість:

- формування не лише напівтонових, але й якісних псевдокольорових зображень, супроводжуваних, 3 метою полегшення їх дешифрації, відповідними чорно-білою чи кольоровою шкалами;

- покадрового накопичення зображення для покращання його якості;

- фіксації у енергонезалежній пам'яті отриманих теплових зображень;

- зв’язку з персональним комп'ютером.

3 цією метою ТК повинна бути обладнана цифровим відеопроцесором покадрової обробки сигналу в реальному часі.

Усім вищезазначеним вимогам відповідає двохдіапазонний тепловізійний комплекс, що містить у своєму складі основний канал формування піросигналу та допоміжний - формування відеосигналу, відеопроцесор і видошукач (рис. 6).

У основному каналі ІЧ об'єктив О2 передає на мішень піровідикона ІЧ випромінювання досліджуваного об'єкту. Мішень сприймає зміну в часі ІЧ випромінювання (цю зміну забезпечує періодичне переривання випромінювання спіралевидним модулятором, який обертається двигуном, що живиться від вузла синхроприводу) та створює на своїй поверхні відповідний електричний заряд. Цей заряд зчитується електронним променем та передається на формувач піросигналу. Растрову розгортку променя забезпечують фокусуючевідхилювальний комплекс, блок керування режимом та генератор розгортки. На час зворотного ходу блок керування режимом переводить піровідикон у режим “швидких електронів” для забезпечення формування т.зв. “п’єдесталу”, відносно рівня якого формується корисна складова піросигналу.

Зображення, отримане у видимому діапазоні випромінення, формується у допоміжному каналі за допомогою об'єктиву О1 та ПЗ3-відеокамери.

Для забезпечення ріномасштабності зображень, отриманих у ІЧ та видимому діапазонах, оптичні параметри $\mathrm{O} 1$ та О2, а також розміри мішеней обох детекторів повинні бути якомога більше близькими. Почергова обробка обох зображень здійснюється у відеопроцесорі (при цьому обробка відеосигналу передбачає лише його оцифровку 3 метою подальшого запису у енергонезалежну пам'ять 


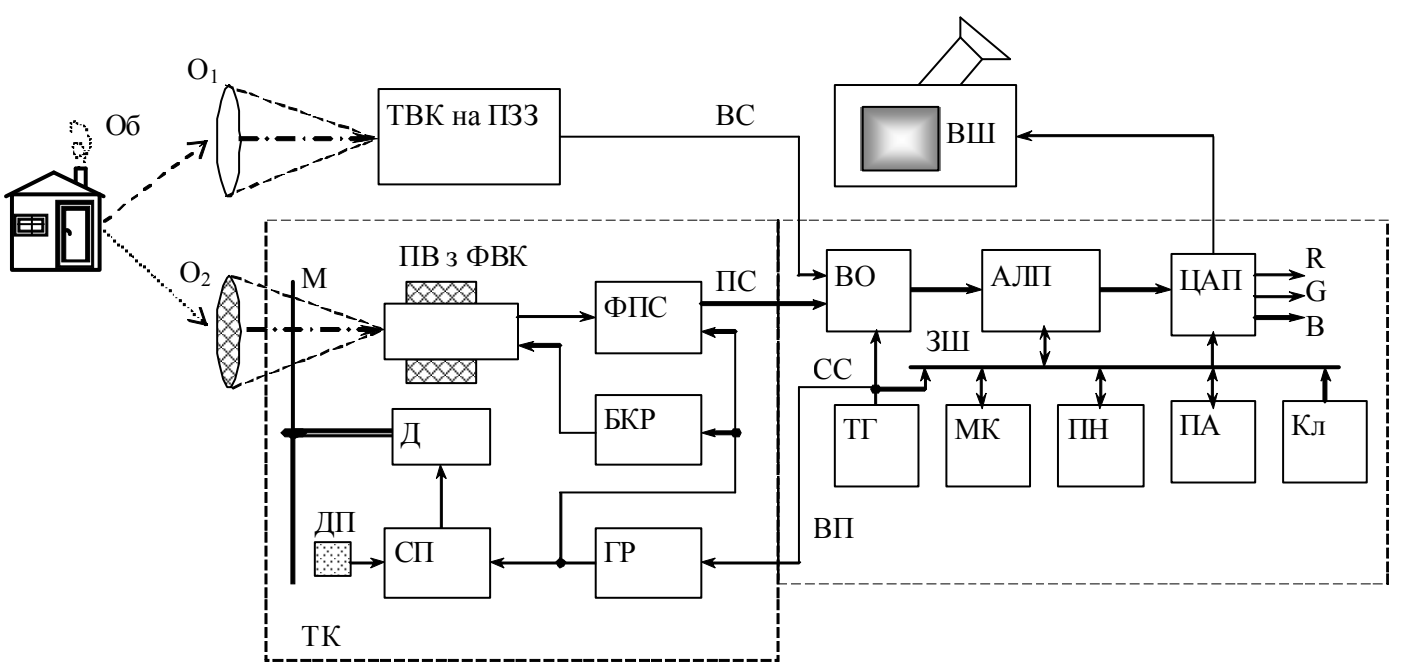

Рис. 6. Структура дводіапазонного тепловізійного комплексу, де:

Об - досліджуваний об'єкт;

ТВК - ПЗЗ-камера;

М - модулятор ІЧ випромінення;

ПВ - піровідикон;

Д-двигун;

СП - синхропривід;

ГР - генератор розгортки;

ВШ - видошукач;

ВП - відеопроцесор;

ТГ - тактовий генератор;

МК - мікроконтролер;

Кл - клавіатура;

ЗШ - загальна шина;
$\mathrm{O}_{1}, \mathrm{O}_{2}$ - об'єктиви каналів видимого та ІЧ діапазонів;

ТК - тепловізійна камера;

ДП - давач положення модулятора;

ФВК - фокусуюче-відхилювальний комплекс;

ФПС - формувач піросигналу;

ВС, ПС - відео- та піросигнали;

ВО - вузол оцифровування;

АЛП - арифметико-логічний пристрій;

ЦАП - цифро-аналоговий перетворювач,

ПН, ПА - пам'ять, відповідно, накопичення та архіву;

С - синхросигнали телевізійної розгортки;

$\mathrm{R}, \mathrm{G}, \mathrm{B}$ - сигали кольорового видимого або псевдокольорового теплового зображень. архіву). Сформовані у режимі реального часу та запам'ятовані зображення можуть бути відтворені видошукачем за допомогою ЦАП, а також передані у ПК через послідовний інтерфейс RS-232. Обмін між вузлами відеопроцесора здійснюється по загальній шині. Режими роботи відеопроцесора та комплексу в цілому задаються оператором 3 клавіатури.

Наявність видошукача дозволяє оператору легко контролювати процес запису зображень як у напівтоновому, так i y псевдокольоровому представленні.

Корисні складові піросигналу за відкритого i закритого модуляторів мають протилежну полярність, при цьому полярність п’єдесталу не змінюється. Покадрове віднімання в АЛП піросигналів, отриманих у різних фазах роботи модулятора, дає змогу приблизно удвічі збільшити амплітуду корисної складової та значно зменшити вплив завад - насамперед складової п'єдесталу. АЛП може також працювати у режимі покадрового накопичення; при цьому усереднення заданої кількості накопичених кадрів уможливлює значно покращати якість теплового зображення за рахунок усунення 3 піросигналу складових несинхронних завад. Сформовані кадри теплового зображення так само, як і кадри видимого, можуть бути відтворені на видошукачі, записані у пам'ять архіву та передані у ПК, де відбувається подальша цифрова обробка отриманих зображень.

\section{Висновки}

Побудова універсального дводіапазонного тепловізійного комплексу 3 процесорним керуванням уможливить отримання комплексного зображення. Такий комплекс зможе знайти широке застосування не тільки для спостереження за тепловими об'єктами, але й при вирішенні практичних питань у багатьох сферах діяльності людини - військовій справі, виробництві, медицині, науковому експерименті тощо.

Перспективи подальших розвідок у даному напрямку автори вбачають у збільшенні кількості джерел вхідної інформації тепловізійного комплексу для формування комплексних зображень шляхом збільшення кількості детекторів спектральних діапазонів, а також у дослідженні можливостей застосування пропонованого комплексу в інших системах багатоспектрального синтезу, що працюють у режимі реального часу. 


\section{Список літератури}

1. ГоссоргЖ. Инфракрасная термография Ж. Госсорг. - М.: Мир, 1988. - 216 c.

2. Волков В.Г. Приборы ночного видения новых поколений / В.Г. Волков // Специальная Техника, 2001. № $5 .-$ C. $2-8$.

3. Боженко B.I Підвищення інформативності тепловізійної системи шляхом формування композитних зображень / В.І. Боженко, П.О. Кондратов // Системи обробки інформації. - 2007. - Вип. 8 (66). - C. 16- 17.

4. Рекламно-інформаційні матеріали фірми AGEMA Infrared Systems AB, 1999-2009.

5. Pat.4679068 US, Int.Cl. H04N 5/33. "Composite Visible-Thermal Infrared Imaging System”: R.Lillquist. Pub. 7.07.87.
6. Pat.4751571 US, Int.Cl. H04N 5/33. "Composite Visible-Thermal Infrared Imaging Apparatus": R.Lillquist. Pub. 29.07.87.

7. Bozhenko V., Kondratov P., Shkljarskij V. Probable Methods of Complex Images Formation // Modern Problems of Radio Engeneering, Telecommunications and Computer Science - $10^{\text {th }}$ International Conference TCSET'2008. - Lviv: $N Y$ "LP", 2008. - P. $357-358$.

Надійшла до редакиії 30.09.2009 p.

Рецензент: доктор технічних наук, старший науковий співробітник В.М. Корольов, Академія сухопутних військ імені гетьмана Петра Сагайдачного, Львів.

\title{
ВОЗМОЖНЫЕ МЕТОДЫ ФОРМИРОВАНИЯ КОМПЛЕКСНЫХ ТЕПЛОВИЗИОННЫХ ИЗОБРАЖЕНИЙ
}

\author{
В.И. Боженко, Р.В. Казмирчук, В.И. Шклярский, П.А.Кондратов
}

\begin{abstract}
Многоспектральное изображение существенно облегчает контроль и идентификацию объектов. Переход от отдельных изображений в разных спектральных диапазонах к формированию комплексного изображения существенно повынает эффективность мониторинга объекта исследований. В данной статье рассмотрень различные способы реализации многоспектральных устройств, проблемы, возникающие при этом, и пути их преодоления. Предложен комплекс обработки тепловизионного изображения, предназначенный для формирования комплексного двухдиапазонного изображения.
\end{abstract}

Ключевые слова: многоспектральный мониторинг, комплексное изображение, тепловизионная камера.

\section{POSSIBLE METHODS OF COMPLEX THERMAL IMAGES FORMING}

V.I. Bozhenko, R.V. Kazmirchuk, V.I. Shkliarskiy, P.A. Kondratov

Multispectral image substantially simplifies the control and identification of the objects. Moving from separated images in different spectral diapasons to the complex image forming substantially increases the research object monitoring effectiveness. In this article different methods of multispectral devises realization, problems, appearing with that, and the ways of their solution are viewed. The complex of thermal image processing, aimed at complex two-diapason image creation, is proposed.

Keywords: multispectral monitoring, complex image, thermal camera. 